\title{
CIRCULAR ECONOMY IN HOUSING ARCHITECTURE: METHODS OF IMPLEMENTATION
}

\author{
Łukasz Kamil Mazur ${ }^{\boxplus}$ \\ Institute of Civil Engineering, Warsaw University of Life Sciences - SGGW, Warsaw, Poland
}

\begin{abstract}
The aim of the article is an analysis of the possibility of introducing housing construction into a more sustainable and ecological level, through the concept of circular economy (CE) in the construction industry. Housing is an important part of the economy and construction sector. Development of this sector results from a growing population in urban areas and the need of modernization of existing residential buildings. Contemporary realizations of housing environments should consider the reduction of the negative impact on the natural environment. This is possible to achieve by reducing the use of natural resources and start using recycled materials. This assumption belongs to the basic CE task, which allows a recirculation of building materials. To discuss the basic work, the assumptions used a non-reactive desk research method. The review of scientific publications and reports included a subject: (i) concept of CE, (ii) CE in construction sector, (iii) $\mathrm{CE}$ in housing construction. The second part of the study analysed innovative ways of using recycled materials and their implementation in new building materials (used in residential construction). Eco-innovation overview includes: (i) bricks from plastic waste, (ii) 3D printing of buildings from recycled materials, (iii) facade plates made of recycling materials. In discussion, the research revealed a number of barriers preventing the effective implementation of $\mathrm{CE}$ in the construction industry. The discussion indicates three potential barriers to the implementation of $\mathrm{CE}$ in housing environments: (i) social responsibility of the construction industry, (ii) recycling of building materials, (iii) building material resulting from recycling. Final paper conclusions confirming the rightness to implement $\mathrm{CE}$ concept in housing construction, thanks to which it will be possible to reduce the negative impact on the environment.
\end{abstract}

Key words: architecture, housing, city, building disassembly, eco-innovation, circular economy

\section{INTRODUCTION}

In the 21 st century our planet stands against new global challenges, e.g. climate change, environmental, and air pollution. This is just an example of the negative factors that our civilisation has to face. A factor that also deteriorates this situation is an increasing number of world population. Researchers predict that by the end of 2025 the number of people will exceed
8 billion $^{1}$. In the nearby future, human population will be concentrated in already urbanized areas, causing that by $2050,2 / 3$ of the world's population will be living in cities. Needs of new city's residents and the consumption of natural resources will be expanding at an alarming rate. Today, the economy is based on more than $2 / 3$ on non-renewable natural resources, of which the construction sector consumes more than $30 \%$ (Organisation for Economic Co-operation and

${ }^{1}$ The World Population Review website www.worldpopulationreview.com [access 24.03.2021]. 
Development [OECD], 2015). Construction sector must reduce the use of natural resources and start using recycling materials. One of the possible ways to reuse of building materials is the application of the concept of a circular economy (CE).

The presented paper discusses the possibility of using the $\mathrm{CE}$ in housing construction. The scope of this work covers: (i) dismantling, (ii) reuse of building materials (also home furnishings), and (iii) sustainable eco-innovation. The reasons for research on these problems arise from the possibility of improving the negative impact of the construction industry on the environment. The number of housing buildings is constantly growing, and existing buildings require a periodic modernization (Firlagg, 2019). An example may be residents of the European Union who live in $46.0 \%$ in flats and over $53.3 \%$ in single-family houses (Eurostat, 2020a). It is estimated that $80 \%$ of EU houses that will exist in 2050 has already been built. Therefore, the existing housing buildings undergoing modernization will increase the emission of carbon dioxide $\left(\mathrm{CO}_{2}\right)$ into the atmosphere. One possible way to reduce this emission is to implement the CE concept in the construction industry. This method is promoted by the EU, which has implemented directives to reduce $\mathrm{CO}_{2}$ emissions in the construction sector in terms of improving the energy efficiency of buildings (Directorate-General for Climate Action [DG CLIMA], 2019). The aim of the presented research is to analyse the possibility of introducing housing to a more sustainable and ecological level by applying the $\mathrm{CE}$ in construction.

\section{MATERIAL AND METHODS}

In the presented work, non-reactive desk research methods were used. The literature study in the first part was to identify and explain the concept of CE in the construction industry. For this purpose, a review of scientific papers and reports included subjects: (i) concept of CE, (ii) $\mathrm{CE}$ in construction sector, (iii) $\mathrm{CE}$ in housing construction. By defining the basic assumptions of the theoretical concept of the $\mathrm{CE}$ and $\mathrm{CE}$ concepts in construction, it was possible to determine the possibility of using CE in housing construction. In the second part of the study innovative ways of using recycled materials and their implementation in new building materials (used in housing construction) were analysed. The presented eco-innovation paragraph describes: (i) bricks from plastic waste, (ii) printing a 3D building with recycled materials, (iii) facade tiles made from recycling materials. Research has been completed by the discussion in which the author refers to the scientific work of other researchers and presents three barriers to $\mathrm{CE}$ in housing construction.

\section{LITERATURE REVIEW}

Housing in CE is an interdisciplinary research theme, including such fields as, e.g. civil engineering (Eberhardt, Birgisdottir \& Birkved, 2020), architecture (Kellner, 2011; Eberhardt, Birgisdottir \& Birkved, 2019) or urban planning (Ellen MacArthur Foundation \& ARUP, 2019; Nerini, Slob, Engström \& Trutnevyte, 2019; Williams, 2019). Research work describe the circulation cycle of the building materials in a closed-loop, including demolishing and dismantling buildings (Marinova, Deetman, Voeta \& Daioglou, 2020). They are an important aspect of international policy and the $\mathrm{EU}$ in the fight against negative climate change (European Commission communications $\operatorname{COM}(2012) 433$, $\operatorname{COM}(2016)$ 763). Transformation of the construction industry, in which the life of the building material does not end with the demolition of the building and waste disposal, is needed not only for economic and social reasons but also for climate protection (United Nations Environment Programme [UNEP], 2009). Examples of building disassembly confirm the rightness of these assumptions and the ability to implement the $\mathrm{CE}$ in the housing sector (Xu, Shen, Liu \& Martek, 2019). On the other hand, recycling of building materials opens opportunities for innovative solutions in housing construction (Kleis, 2013; Zaheer \& David, 2018).

\section{CIRCULAR ECONOMY}

From the beginnings of life on the Earth, the humanity uses natural resources to satisfy their own needs (Walther, 2014). During the extraction and processing of natural resources, we can produce i.a. building materials - this is the basis of a modern economy known as linear: an economy in which a building material after its useful life is treated as waste destined for 
incineration or storage in the landfill (Smol, Kulczycka, Henclik, Gorazda \& Wzorek, 2015). This system is devastating our natural environment and gradually leads to a natural disaster. Scientists can see the solution to this problem in transforming the industry into a closed loop where materials can be reused (Leube \& Walcher, 2017).

The CE concept aims to eliminate the waste of materials by bringing them back into second use. Looping natural resources in the life cycle reduces the need to extract natural resources (Fig. 1).

An example is aluminium, commonly used as a building material on construction sites all over the world. It is estimated that all aluminium products in 2006 were used in $32 \%$ in the construction sector and $28 \%$ in the production of cables (which are used also in construction) (Scamans, Birbilis \& Buchheit, 2010). Aluminium is produced from bauxite - a sedimentary rock with the largest natural deposits in Australia (Scamans et al., 2010). Extracting, transporting, and processing of bauxite requires a large amount of energy, whose production is harmful to the natural environment (Gadgil \& Cherukumilli, 2019). At the same time, only $5 \%$ of the primary energy is needed to recycle aluminium into other building materials (Bulei, Kiss \& Alexa,
2021). Aluminium as a material has an endless potential for reuse, it is estimated that the recycling rate of aluminium in construction is very high (85-95\%) (Global Aluminium Recycling Committee [GARC], 2009).

The main goal of the $\mathrm{CE}$ is the harmonious development of humanity and the introduction of sustainability elements into the economy without adverse affecting on the existing ecosystem. Once extracted, the raw material can be used in various ways, maximizing its life cycle (Leube \& Walcher, 2017). The determination of all environmental impacts of the construction material is possible by analysing the life cycle assessment (LCA). The analysis starts from the extraction of the natural resource, through the production, use stage, and disposal (end of life). Thanks to this research method, it is possible to analyse and fully assess the product's impact on the natural environment (Vilches, Garcia-Martinez \& Sanchez-Montanes, 2017).

\section{Circular economy in construction sector}

The construction industry is responsible for one-third of global $\mathrm{CO}_{2}$ emission and produces the most waste $(30 \%)$ among all sectors of the economy - causing the greatest damage to the natural environment (Thelen et al., 2018).

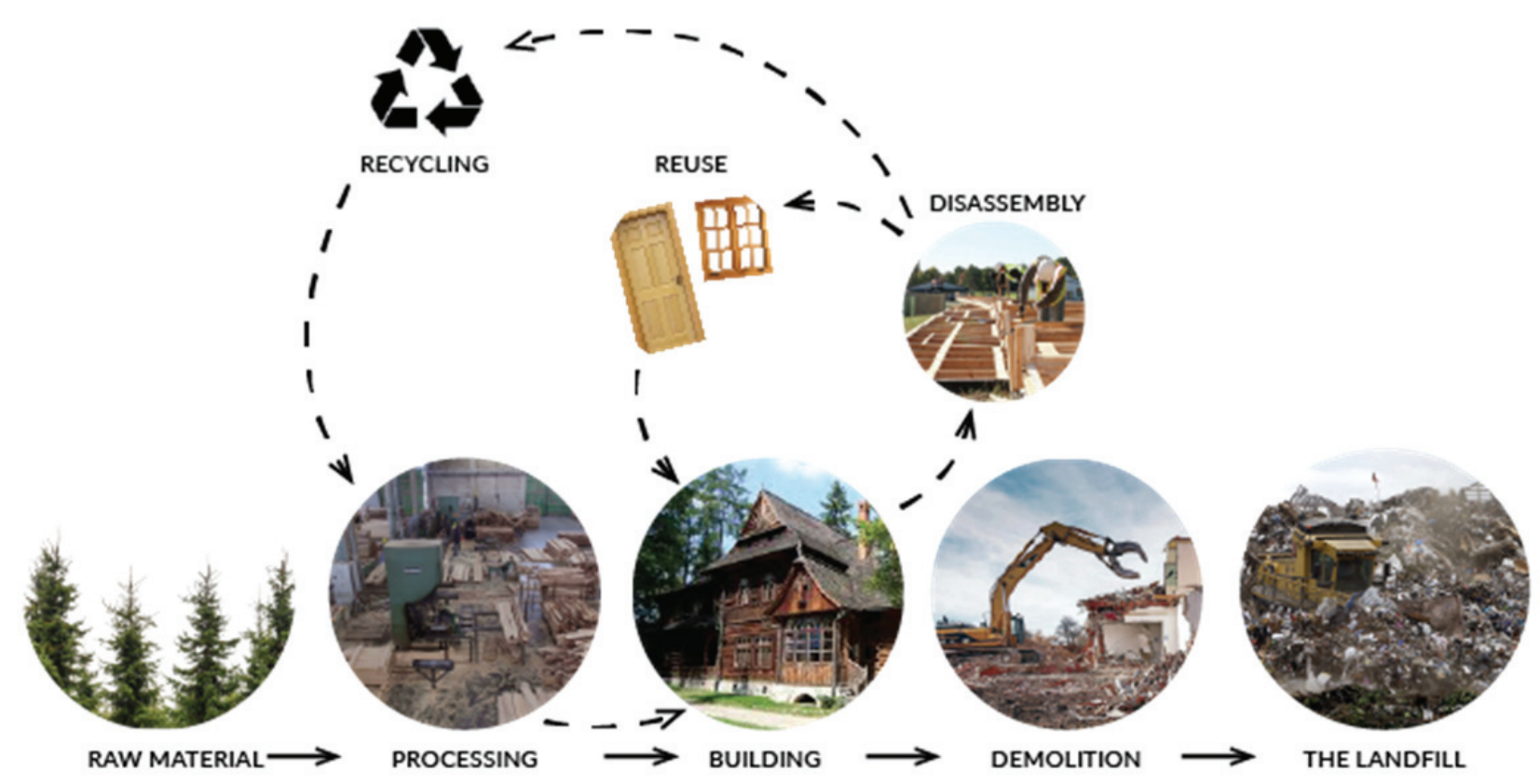

Fig. 1. Scheme of linear and circular economy model in construction ratio (own elaboration) 
The expansion of the construction industry is visible and undeniable - the building currently occupies an average of $30 \%$ more land than in 1990 (OECD, 2017). This situation caused an increase in demand for the necessary building materials, whose extraction doubled since 1980 (OECD, 2015). Despite such facts, in the ongoing public debate on climate change, the role and responsibilities of the construction industry are not as publicized as, e.g. in the case of plastics producers. However, the construction industry has many possible responses to the crisis, e.g. the large-scale use of recycled raw materials or the use of technology that reuses materials can significantly improve the natural environment (Ginga, Ongpengand \& Daly, 2020).

The construction waste market has great potential for introducing a systematic and cost-effective recycling system. In the EU alone, $36.4 \%$ of waste comes from the construction industry, e.g. from demolition works - which is an average $1.82 \mathrm{t}$ of waste per inhabitant in 2018 (Eurostat, 2020b). The problem with reusing materials lies in the dominant model of a linear economy (build, use, demolish), which is directed to a quick profit (Mestre \& Cooper, 2017). In practice, this means that disposal and landfilling of construction waste is disproportionately cheaper than reusing it. The investors of a new designed building are not interested in what will happen to the property after selling it and when the warranty period its end. Notably, in the use of more expensive eco-friendly materials or technologies, which positively affect the entire life cycle of the building. An example may be a common use of cement with a greater admixture of alite in construction structures, which allows faster bonding and shorter construction time. At the same time, this material increases the strength of the connection, which does not allow the complete recycling of the brick (Bukowski \& Fabrycka, 2019).

\section{Circular housing construction}

One of the ways to apply a fully closed loop in construction is more frequent deconstruction and recycling of buildings. Construction works usually involve dismantling the building by a manual method, which enables recovering as many materials as possible, and then the building materials are processed or renovated. This is the opposite of the traditional linear economy, where the demolition of the building ends with the use of heavy machines to destroy the structure and storing the materials in a landfill. Reuse of building materials has become the idea of many social organizations, whose founders see in the recycling an opportunity to improve the situation of the local community (Delta Institute, 2018).

An example of such activities is the organization Delta Institute which, since 1998, has been dealing with the environmental problems of the inhabitants of the Midwest of the United States². In 2009, the organization opened in Chicago the first warehouse for recycled building materials - Rebuilding Exchange. The initiative was to counteract local community problems: make construction materials available at more affordable prices and help the unemployed inhabitants find jobs after training and appropriate preparation in the field of construction recycling. A retail warehouse with an area of over $2,300 \mathrm{~m}^{2}$ offers inexpensive building materials which make it easier and cheaper to restore the historic buildings of the city from the 20th century. The Rebuilding Exchange magazine also runs i.a. workshops, where one can learn from local artists and artisans how to bring recycled materials back to life, and educational classes on the safe demolition of buildings ${ }^{3}$.

The Delta Institute estimates that only $5-15 \%$ of the materials from the demolition of a residential building are not suitable for recycling, while $25 \%$ of the materials can be directly used (e.g. windows, doors) and $70 \%$ of the raw material can be processed (e.g. concrete) - Figure 2. The organization proved that the deconstruction of a house - can pay off and generate additional jobs for construction workers, warehouse workers, sellers, renovators, and people conducting training in the field of construction skills (disassembly and renovation). Experts say that each person employed in the building deconstruction will create another seven jobs in material processing (Delta Institute, 2018).

\footnotetext{
${ }^{2}$ The Delta Institute website www.delta-institute.org/ [access 15.03.2021].

${ }^{3}$ The Rebuilding Exchange website www.rebuildingexchange.org [access 15.03.2021].
} 


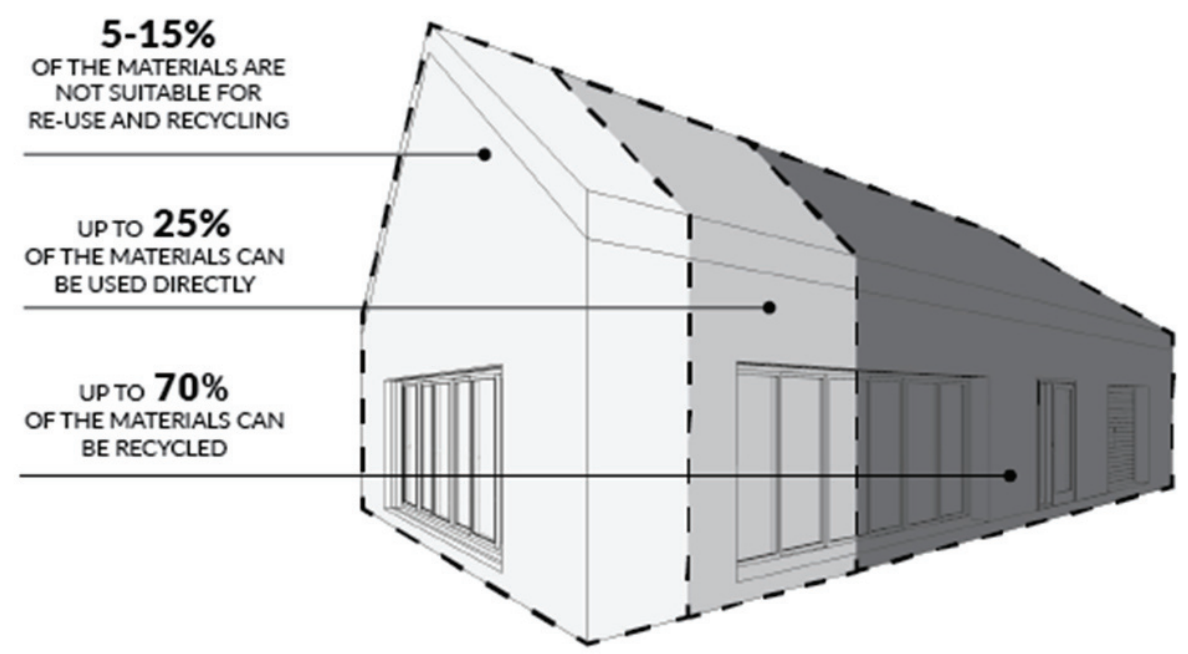

Fig. 2. Level deconstruction of a residential building and recycling of construction material (own elaboration based on Delta Institute, 2018)

The positive impact of dismantling buildings on society has been recognized and spread to other American cities. Detroit, once a city with over 1.8 million inhabitants, began to struggle with the problem of falling numbers of residents, lack of jobs, and deteriorating the technical condition of housing environments, which led to arson. In 2004, the Detroit authorities demolished 2,600 residential buildings, and in the south-eastern state of Michigan, more than 4,000. The difficult economic situation in one of the America's largest metropolises even ended in bankruptcy in 2013. That is when the Architectural Salvage Warehouse of Detroit (ASWD) initiative was born, which is a warehouse of recycled building materials. His founders decided to try to restore historical regional materials by reusing them (the ASWD slogan "Transforming WASTE into OPPORTUNITY" $)^{4}$. By recycling building materials, they also counteract environmental pollution and provide decent, inexpensive interior materials to local lowand middle-income families. The ASWD foundation provides all financial profits to modernize and protect historical buildings and subsidies for other organizations.

\section{ECO-INNOVATION}

Research on ecological innovation and implementation in housing construction is a challenge for the construction sector for the next decades. Thanks to the innovative idea, we are able to reduce the negative impact of construction on the natural environment. Effective implementation of eco-innovation on a large scale will allow the implementation of housing environments on a more sustainable and ecological level. Thanks to this solution, we are able to reuse the construction material in accordance with the CE concept.

In the further part of the work, three innovative ideas will be discussed for the use of recycled materials: (i) bricks from plastic waste, (ii) printing a 3D building with recycled materials, (iii) facade tiles made from recycling materials.

\section{Bricks from plastic waste}

An interesting idea for the use of ubiquitous plastic has been developed by the founders of the Colombian startup Conceptos Plásticos - converting waste into a new building material. Their idea is to turn this material into a high-quality brick for building houses for

\footnotetext{
${ }^{4}$ The Architecture Salvage Warehouse Detroit website www.aswdetroit.org [access 15.08.2020].
} 
the most needy. A residential building is built in just five days and is $30 \%$ cheaper. The brick, according to the founders, should withstand at least 500 years - at least the same as plastic bottles (Lundell \& Thomas, 2020). The start-up was launched in 2011 by cooperating with companies in Bogota to collect secondary raw materials. Prepared and purified plastic bottles are melted with additional ingredients, in this process is created a new material called Bloqueplas. Bloqueplas as material is poured into special forms, in which bricks are formed. An important aspect of the project is the simplicity of the building system, which is based on connecting individual blocks like Lego blocks. This allows to build houses even unqualified construction workers, regardless of their skills or knowledge. In 2015, in the city of Guapi (in the Colombia region of Cauca), 42 houses were built from this material, in which $120 \mathrm{t}$ of recycled plastic was used (Winkless, 2016).

\section{Printing a 3D building with recycled materials}

An example of how modern technologies and ecology can complement each other is a five-storey residential building in Shanghai. The world's largest 3D printer with a length of $150 \mathrm{~m}$ and a height of $6 \mathrm{~m}$ was used for its structures. The WinSun company produced the first high-rise residential building in the world, with a total area of $1,100 \mathrm{~m}^{2}$, using the printing method. Building material, used for printing, was made of recycled construction waste, including concrete, fiberglass, and sand. The structure was created by overlapping successive layers of building material. The construction process of printing buildings has many advantages: the time needed to build a building is reduced by $30 \%$, the workload of construction workers is reduced by $80 \%$, and above all, savings in material reach up to $60 \%$ (Yihe, 2019). Ma Yi, the founder of WinSun, said „Industrial waste from demolished buildings destroys our environment, but thanks to 3D printing we are able to recycle construction waste and transform it into new ones. This will create a much safer workplace for workers and significantly reduce construction costs" (Russon, 2014).

\section{Facade tiles made from recycling materials}

Among the negative opinions on the use of recycling materials, the most popular concerns its worse quality. An example, which shows that these materials can be exceptional, is a Dutch start-up - StoneCycling, which made the facade of a tenement house in Rotterdam. The investors and at the same time designers were a young couple of architects who formed the Architectuur MAKEN studio, who decided to finish their house and studio with a recycled facade. To build a façade, StoneCycling needed $15 \mathrm{t}$ of waste material, e.g. ceramic, glass, and clay waste, which was collected within a radius of $160 \mathrm{~km}$ from a factory located in the south-east of the Netherlands. $5^{5}$ Thanks to the unique recipe, i.e. the mix of construction waste, new recycled bricks are created in the shades of purple, blue, red, green, black, and yellow (Budds, 2019).

\section{RESULTS AND DISCUSSION}

The presented paper was prepared on the basis of literature research and enriched with innovative examples of the implementation of the $\mathrm{CE}$ in the construction sector. It was confirmed that there is a need to design a housing environment on the ideals of sustainable development goals. Where new residential buildings as well as modernized housing will reduce the use of natural resources and reduce $\mathrm{CO}_{2}$ emissions to the atmosphere.

To efficiently implement $\mathrm{CE}$, the construction sector must take a series of deep reforms, which will reduce the negative impact on the natural environment (Núñez-Cacho, Górecki, Molina \& Corpas-Iglesias, 2018). Introduction of a closed-loop material is a difficult challenge for the entire construction sector, starting from obtaining material, production, through a construction project and construction itself, and ending with the deconstruction and recycling of the building. The implementation of CE in construction is associated with overcoming a number of barriers that prevent efficient material circulation. To overcome the barriers, there are increasing scientific works which discuss the research problem in detail.

${ }^{5}$ The StoneCycling website www.stonecycling.com [access 15.03.2021]. 
According to the research by Fritz Benachio, Carmo Duarte Freitas and Tavares (2020), the number of publications on CE in the construction sector in 2019 has doubled relative to the previous year (confirming the increased interest in research). Among the numerous scientific works describing barriers, the publication of Mahpour (2018) should be pointed out, which identified 22 potential causes of barriers and grouped them in three categories: behavioural, technical or legal deficiencies.

Further part of the discussion is divided into three potential barriers occurring in particular in residential facilities: (i) social responsibility of the construction industry, (ii) recycling of building materials, (iii) building material resulting from recycling.

\section{Social responsibility of the construction industry} The deconstruction of the building in aim to obtain building materials for reuse and recycling causes positive social factors. Social responsibility factor is understood here as a conscious realization of buildings by public administration companies using $\mathrm{CE}$ concept (Núñez-Cacho et al., 2018). In addition, the deconstruction and recycling of the building may affect the improvement of the living conditions of the local community - the activities of the Delta Institute are examples $(2018,2021)$.

\section{Recycling of building materials}

Effective sourcing of building materials for recycling and reuse requires analysing the barriers responsible for the technical solution. These barriers can be divided into three levels: materials, product, and/or building (Tebbatt, Osmani, Thorpe \& Thornback, 2017). Effective deconstruction of the building and acquiring recycling materials will be possible thanks to the preparation of a suitable construction project, including its adaptability, flexibility, and final deconstruction plan. It should also be emphasized how important it is to make preliminary recycling on the site of built waste. Thanks to which it will be possible to directly use them with low cost and energy effort, e.g. in the warehouses of building materials ${ }^{6}$.

\section{Building materials resulting from recycling}

The discussed examples of eco-innovations prove that it is possible to use waste not only from construction but also from other economy sectors to the implementation in new building materials. Examples of bricks from plastic waste (Winkless, 2016), 3D printing of a building with recycled materials (Yihe, 2019), and facade tiles made from recycling materials (Stonecycling, 2021) prove that a new construction material resulting from recycling may qualitatively not differ from materials produced from natural raw materials. The problem in the implementation of new building materials resulting from the recycling of raw materials may be uncertainty in the prices of material resources in the future (Morgan, 2014). The building material of the initial low value may not be subjected to recycling - mostly for economic reasons and the cost of processing. Investors having cheap construction materials from natural resources may not decide to cover additional costs and use a recycling material (Tebbatt et al., 2017).

\section{CONCLUSIONS}

Times in which construction waste was treated as unnecessary trash have come to an end. Recycling materials will be valued on a par with natural resources, what will reduce their extraction. It seems to be important to use the recycled waste materials from disassembly and renovation buildings, because $1 / 4$ of them can be directly used in another construction site. The construction waste market has a great potential to introduce innovative and systematic eco-friendly technologies - which reuse materials from waste. The future of the construction industry is gradually moving towards in a closed material loop, causing a reduction in the necessary financial outlays and the time needed to build and furnish an apartment. Recycling of building materials has a positive effect on the economy, local community, and waste management. The idea of CE reduces the demand for energy needed to extract the raw material, transport and its production - reducing the negative impact on the natural environment - and respects the need for future generations.

\footnotetext{
${ }^{6}$ The Architecture Salvage Warehouse Detroit website www.aswdetroit.org [access 15.08.2020].
} 


\section{REFERENCES}

Budds, D. (2016-10-26). This Dutch Company Turns Demolished Buildings into Beautiful Materials. Fast Company. Retrieved from: https://www.fastcompany.com/3064915/this-dutch-company-turnsdemolished-buildings-into-beautiful-materials [access 15.03.2021].

Bukowski, H. \& Fabrycka, W. (2019). Budownictwo w obiegu zamkniętym $w$ praktyce. Warszawa: INNOWO. Retrieved from: https://innowo.org/userfiles/ publikacje/Budownictwo\%20w\%20obiegu\%20zamk ni $\%$ C4\%99tym $\% 20 \mathrm{w} \% 20$ praktyce_raport.pdf [access 15.03.2021].

Bulei, C., Kiss, I. \& Alexa, V. (2021). Development of metal matrix composites using recycled secondary raw materials from aluminium wastes. Materials Today: Proceedings, 45, 4143-4149. https://doi.org/10.1016/ j.matpr.2020.11.926

Communication from the Commission to the European Parliament and the Council. Strategy for the sustainable competitiveness of the construction sector and its enterprises. COM(2012) 433 final.

Communication from the Commission to the European Parliament, the Council, the European Economic and Social Committee, the Committee of the Regions, and the European Investment Bank. Accelerating Clean Energy Innovation. $\mathrm{COM}(2016) 763$ final.

Directorate-General for Climate Action [DG CLIMA] (2019). Going climate-neutral by 2050. Luxembourg: Publications Office of the European Union.

Delta Institute (2018). Deconstruction \& building material reuse: a tool for local governments \& economic development practitioner. Chicago: Delta Institute. Retrieved from: www.delta-institute.org/wp-content/uploads/2018/05/Deconstruction-Go-Guide-6-13-18-.pdf [access 24.01.2021].

Eberhardt, L. C. M., Birgisdottir, H. \& Birkved, M. (2019). Potential of Circular Economy in Sustainable Buildings. IOP Conference Series: Materials Science and Engineering, 471 (9), 1-10. https://doi.org/10.1088/1757899X/471/9/092051

Eberhardt, L. C. M., Birgisdottir, H. \& Birkved, M. (2020-06-23). Building design and construction strategies for a circular economy. Architectural Engineering and Design Management. https://doi.org/10.1080/17452007.20 20.1781588

Ellen MacArthur Foundation \& ARUP (2019). Circular economy in cities. Ellen MacArthur Foundation.
Retrieved from: www.ellenmacarthurfoundation.org /assets/downloads/Buildings_All_Mar19.pdf [access 29.03.2021].

Eurostat (2020a). Housing statistics. Housing quality. Retrieved from: www.ec.europa.eu/eurostat/statistics-explained/index.php/Housing_statistics\#Housing_quality [access 24.03.2021].

Eurostat (2020b). Waste statistics. Total waste generation [env_wasgen]. Retrieved from: www.ec.europa. eu/eurostat/statistics-explained/index.php/Waste statistics\#Total_waste_generation [access 15.08.2020].

Firląg, S. (2019). Kompleksowa termomodernizacja budynków jednorodzinnych. Warszawa: Fundacja Ziemia i Ludzie.

Fritz Benachio, G. L., Carmo Duarte Freitas, M. \& Tavares, S. F. (2020). Circular economy in the construction industry: A systematic literature review. Journal of Cleaner Production, 260, 121046. https://doi.org/10.1016/ j.jclepro.2020.121046

Gadgil, A. J. \& Cherukumilli, K. (2019). Advances in Water Purification Techniques. Meeting the Needs of Developed and Developing Countries. In S. Ahuja (Ed.), Addressing Groundwater Fluoride Contamination Using Inexpensively Processed Bauxite (pp. 291-325). Calabash: Elsevier. https://doi.org/10.1016/B978-0-12814790-0.00012-0

Ginga, C. P., Ongpengand, J. M. C. \& Daly, M. K. M. (2020). Circular Economy on Construction and Demolition Waste: A Literature Review on Material Recovery and Production. Materials, 13, 2970. https://doi. org/10.3390/ma13132970

Global Aluminium Recycling Committee [GARC] (2009). Global Aluminium Recycling: A Cornerstone of Sustainable Development. Haymarket-London: International Aluminium Institute. Retrieved from: www.world-aluminium.org/media/filer_public/2013/01/15/f10000181. pdf [access 15.03.2021].

Kellner, J. (2011). Housing Reclaimed: Sustainable Homes for Next to Nothing. Canada: New Society Publishers.

Kleis, B. (2013). Upcycle house - Genbrug fra inderst til yderst. Odense: Realdania Byg. Retrieved from: www. realdaniabyogbygklubben.dk/media/1803/minico2husene-upcycle-house.pdf [access 29.03.2021].

Leube, M. \& Walcher, D. (2017). Designing for the next (Circular) Economy. An appeal to renew the Curricula of Design Schools. The Design Journal, 20, 492-501. https://doi.org/10.1080/14606925.2017.1352999

Lundell, C. \& Thomas, J. (2020). PET: Polyethylene Terephthalate - The Ubiquitous $500 \mathrm{ml}$ Water Bottle. In 
G. Di Bucchianico et al. (Eds.), Advances in Industrial Design. AHFE 2020. Advances in Intelligent Systems and Computing. Vol. 1202. Cham: Springer. https://doi. org/10.1007/978-3-030-51194-4_33

Mahpour, A. (2018). Prioritizing barriers to adopt circular economy in construction and demolition waste management. Resources, Conservation \& Recycling, 134, 216 -227. https://doi.org/10.1016/j.resconrec.2018.01.026

Marinova, S., Deetman, S., Voeta, E. \& Daioglou, V. (2020). Global construction materials database and stock analysis of residential buildings between 1970-2050. Journal of Cleaner Production, 247, 119146. https://doi. org/10.1016/j.jclepro.2019.119146

Mestre, A. \& Cooper, T. (2017). Circular Product Design. A Multiple Loops Life Cycle Design Approach for the Circular Economy. The Design Journal, 20, 1620-1635. https://doi.org/10.1080/14606925.2017.1352686

Morgan, J. (2014). The Great Resource Price Shock. London: Green Alliance.

Nerini, F. F., Slob, A., Engström, E. R. \& Trutnevyte, E. (2019). A Research and Innovation Agenda for Zero-Emission European Cities. Sustainability, 11, 1692. https://doi.org/10.3390/su11061692

Núñez-Cacho, P., Górecki, J., Molina, V. \& Corpas-Iglesias, A. F. (2018). New Measures of Circular Economy Thinking in Construction Companies. Journal of EU Research in Business, 2018, 909360. https://doi. org/10.5171/2018.909360

Organisation for Economic Co-operation and Development [OECD] (2015). Material Resources, Productivity and the Environment, OECD Green Growth Studies. Paris: OECD Publishing. https://doi.org/10.1787/9789264190 504-en

Organisation for Economic Co-operation and Development [OECD] (2017). Green Growth Indicators 2017, OECD Green Growth Studies. Paris: OECD Publishing. https:// doi.org/10.1787/9789264268586-en

Russon, M-A. (2014-04-24). China: Recycled Concrete Houses 3D-Printed in 24 Hours. International Business Times. Retrieved from: www.ibtimes.co.uk/china-recycled-concrete-houses-3d-printed-24-hours-1445981 [access 15.08.2020].

Scamans, G. M., Birbilis, N. \& Buchheit, R. G. (2010). Corrosion of Aluminum and its Alloys. Shreir's Corrosion, 3, 1974-2010. https://doi.org/10.1016/B978044452787-5.00095-0

Smol, M., Kulczycka, J., Henclik, A., Gorazda, K. \& Wzorek, Z. (2015). The possible use of sewage sludge ash (SSA) in the construction industry as a way towards a circular economy. Journal of Cleaner Production, 95, 45-54. https://doi.org/10.1016/j.jclepro.2015.02.051

Tebbatt, A. K., Osmani, M., Thorpe, T. \& Thornback, J. (2017). Circular economy in construction: current awareness, challenges, and enablers. Waste and Resource Management, 170, 15-24. https://doi.org/10.1680/ jwarm.16.00011

Thelen, D., Acoleyen, V. M., Huurman, W., Thomaes, T., Brunschot, V. C., Edgerton, B. \& Kubbinga B. (2018). Scaling the circular built environment pathways for business and government. World Business Council for Sustainable Development \& Circle Economy. Retrieved from: https://docs.wbcsd.org/2018/12/Scaling the_Circular_Built_Environment-pathways_for_business_and government.pdf [access 15.03.2021].

United Nations Environment Programme [UNEP] (200). Building and climate change. Summary for Decision Makers. Nairobi: United Nations Environment Programme. Retrieved from: https://www.uncclearn. org/wp-content/uploads/library/unep207.pdf [access 15.03.2021].

Vilches, A., Garcia-Martinez, A. \& Sanchez-Montanes, B. (2017). Life cycle assessment (LCA) of building refurbishment: a literature review. Energy and Buildings, 135, 1-61. https://doi.org/10.1016/j.enbuild.2016.11.042

Walther, J. V. (2014). Earth's natural resources. Burlington: Jones \& Bartlett Learning.

Williams, J. (2019). Circular cities. Urban Studies, 56 (13), 2746-2762. https://doi.org/10.1177/0042098018806133

Winkless, L. (2016). These Houses Are Built With Blocks Made From Waste Plastic. Retrieved from: www. forbes.com/sites/lauriewinkless/2016/07/21/thesehouses-are-built-with-blocks-made-from-waste-plastic/ \#36632d7d7894 [access 15.08.2020].

Xu, K., Shen, G. Q., Liu, G. \& Martek, I. (2019). Demolition of Existing Buildings in Urban Renewal Projects: A Decision Support System in the China Context. Sustainability, 11 (2), 491. https://doi.org/10.3390/su11020491

Yihe, M. (2019). WINSUN 3DPrinting. New Era of Green Building [presentation]. Retrieved from: www.3dprintetbyggeri.dk/pdf/ IDA $\% 20$ konferencen $\% 20 \mathrm{PP} / 6 . \% 20$ Winsun.pdf [access 15.08.2019].

Zaheer, A. \& David, S. J. (2018). Towards a Circular Economy: A Case Study of Waste Conversion into Housing Units in Cotonou, Benin. Urban Science, 2 (4), 118. https://doi.org/10.3390/urbansci2040118 


\section{GOSPODARKA OBIEGU ZAMKNIĘTEGO W ARCHITEKTURZE MIESZKANIOWEJ: ANALIZA METOD WDROŻENIA}

\section{STRESZCZENIE}

Celem prezentowanego artykułu badawczego jest przeanalizowanie możliwości wprowadzenia budownictwa mieszkaniowego na bardziej zrównoważony poziom poprzez zastosowanie koncepcji gospodarki o obiegu zamkniętym (GOZ). Mieszkalnictwo jest ważną częścią gospodarki i sektora budowlanego. Wzrost w tym sektorze wynika ze wzrostu ludności na obszarach zurbanizowanych i potrzeby modernizacji istniejących zasobów. Współczesne realizacje środowisk mieszkaniowych powinny uwzględniać zmniejszenie negatywnego wpływu na środowisko naturalne. Możliwe jest to poprzez zmniejszenie zapotrzebowania na materiały budowlane pochodzące $z$ surowców naturalnych i rozpoczęcie stosowania materiałów pochodzących z recyklingu. Założenie to należy do podstawowego zadania GOZ, w której następuje obieg zamknięty materiału budowlanego poprzez jego powtórne wykorzystanie. W celu omówienia podstawowych założeń pracy zastosowano metody badań niereaktywne: metoda badawcza desk research. Przegląd publikacji naukowych i raportów obejmowały: (a) podstawy koncepcji GOZ, (b) podstawy koncepcji GOZ w sektorze budowlanym, (c) podstawy koncepcji GOZ w budownictwie mieszkaniowym. W drugiej części badań analizowano innowacyjne sposoby wykorzystania materiałów pochodzących z recyklingu do realizacji nowych materiałów budowlanych. Przedstawiono ekoinnowacje: (a) cegły z odpadów z tworzyw sztucznych, (b) druk 3D budynku z materiałów pochodzących z recyklingu, (c) płytki fasadowe wykonane z materiałów recyklingowych. W dyskusji omówiono trzy potencjalne bariery występujące w realizacjach środowisk mieszkaniowych: (1) odpowiedzialność społeczna przemysłu budowlanego, (2) recykling materiałów budowlanych, (3) materiał budowlany powstały z surowca z recyklingu. Wnioski końcowe pracy potwierdzają słuszność wdrożenia koncepcji GOZ w budownictwie mieszkaniowym.

Słowa kluczowe: architektura, architektura mieszkaniowa, miasto, demontaż budynków, ekologiczne innowacje, gospodarka o obiegu zamkniętym 